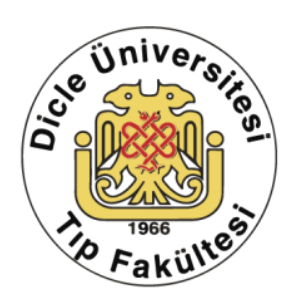

\title{
Toplam Kolesterol, Ldl, Hdl ve Trigliserit Seviyelerinin Yaşa Göre Değişiminin Farklı Regresyon Modelleriyle İncelenmesi
}

\author{
Emre Dirican'1, Cemil Çolak², Zeki Akkuş³ \\ 1 Dicle Üniversitesi, Tıp Fakültesi, Biyoistatistik Anabilim Dalı, Diyarbakir-Türkiye \\ 2 İnönü Üniversitesi Tıp Fakültesi Biyoistatistik Anabilim Dal, Malatya,Türkiye \\ 3 Dicle Üniversitesi Tıp Fakültesi, Biyoistatistik Anabilim Dalı, Diyarbakir-Türkiye
}

Geliş: 09.11.2016; Revizyon: 31.01.2017; Kabul Tarihi: 07.02.2017

\section{Özet}

Amaç: Bu çalışmada hiperlipidemi hastalarının Toplam Kolesterol, LDL, Trigliserit, HDL seviyelerinin farklı regresyon modelleriyle tahmini ve yaşa göre değişiminin belirlenmesi amaçlanmıştır. Bu amaçla, doğrusal ve doğrusal olmayan regresyon modelleri ile analiz yapılmıştır.

Yöntemler: Çalışmamız, İnönü Üniversitesi Turgut Özal Tıp Merkezi Kardiyoloji bölümüne müracaat eden 1278 hiperlipidemili hasta üzerinde gerçekleştirilmiştir. Retrospektif çalışmamızda veri toplama aracı olarak hasta dosyaları ve vaka kayıtları kullanılmıştır. Kayıtlardan toplanan veriler paket programlarla analiz edilerek modellemeler yapılmıştır.

Bulgular: Araştırmamızda 1278 hiperlipidemili hastanın 671'i (\%52,4) erkek ve 607'si $(\% 47,6)$ kadındır. Büyüme eğrilerinin uyumunun incelenmesinde açıklayıcılık katsayısı $\left(R^{2}\right)$, Hata Kareler Ortalaması (HKO), Akaike Bilgi Kriteri ( AIC) ve Schwarz Bilgi Kriteri (SIC) hesapları dikkate alındığında, kadın hastalarda; Kolesterol değerleri için en iyi büyüme modeli Kuadratik model, LDL için Gompertz model, Trigliserit için Lojistik model, HDL için Ustel modeldir. Erkek hastalarda ise; Kolesterol değerleri için en iyi büyüme modeli Gompertz model, LDL için Doğrusal model, Trigliserit için Üstel model, HDL için Doğrusal modeldir.

Sonuç: Doğrusal olmayan hiperlipidemik değerlerin tahmininde değişik modellerin farklı performans gösterdiği belirlenmiştir. Hiperlipidemi değerleri izleminde bu modellerden elde edilen büyüme eğrilerinin kullanılmasının, Kolesterol, LDL, HDL ve Trigliserit değerlerinin tahmin edilebilmesinde ayrıca normal değerlerden sapmaların değerlendirilmesinde yararlı olacağı düşünülmektedir.

Anahtar kelimeler: Doğrusal regresyon, doğrusal olmayan regresyon, uyum iyiliği kriterleri, en küçük kareler yöntemi, en çok olabilirlik yöntemi.

DOI: $10.5798 /$ dicletip. 298613

Yazışma Adresi / Correspondence: Emre Dirican, Dicle Üniversitesi, Tıp Fakültesi, Biyoistatistik Anabilim Dalı 21280, Sur-Diyarbakir, Türkiye Email: emredir44@hotmail.com 


\title{
The Investigation of Total Cholesterol, Ldl, Hdl and Triglycerides Levels with respect to Age by different Regression Models
}

\begin{abstract}
Objective: In the present study, it is aimed to specify the changes in the Total cholesterol, LDL, Triglyceride and HDL levels of hyperlipidemia patients according to age and estimation through several regression models. For that purpose, the analysis was made through linear and non-linear regression models.

Methods: Our study was conducted with 1278 hyperlipidemia patients who applied to İnönü Unversity Turgut Özal Medicine Center Cardiology Department. For our retrospective study, patient folders and case records were used as data gathering tools. The data gathered from records were analyzed through packet programmes for modelling.

Results: In our research, of the 1278 patients, 671 were males (52.4\%) and 607 were females (47.6\%). While analyzing the conformity of the growth curves, for female patients, the best growth model is Quadratic Model for cholesterol values; Gompertz Model for LDL; Logistic Model for Triglyceride; Exponential Model for HDL considering explanatory factor $\left(\mathrm{R}^{2}\right)$, Error Sum of Squares (ESS), Akaike Information Criterion (AIC) and Schwarz Information Criterion (SIC). For male patients, the best growth model for cholesterol values is Gompertz Model; Linear Model for LDL; Exponential Model for Triglyceride and Linear Model for HDL.

Conclusion: It was found out that several models show different performance in the estimation of non-linear hyperlipidemic values. In the follow-ups for hyperlipidemia values, it is thought that using growth curves obtained from those models could be useful for not only estimating cholesterol, LDL, HDL and Triglyceride levels but also analyzing deviations from normal values.
\end{abstract}

Keywords: Linear regression, non-linear regression, goodness of fit criteria, least squares method, maximum likelihood method.

\section{GíRiş}

Regresyon çözümlemesi, değiş̧kenler arasındaki bağıntının en iyi şekilde açıklandığı modellemeye dayanır. Regresyon modeli fonksiyonel bir yapı ile ifade edildikten sonra $\mathrm{bu}$ fonksiyon değerlendirilerek regresyon modelinin doğrusal olup olmadığına karar verilir [1]. İstatistik adına önemli konulardan biri, regresyon modeli kurulduktan sonra bu modelin doğru tahminlemeyi ne kadar yaptığıdır [2]. Böyle durumlarda da uyum iyiliği kriterleri ve doğrusal olmayan modellerin, doğrusal yaklaşıma yakın sonuçlar verip vermediği değerlendirmesi devreye girer.

Doğrusal olmayan modeller, bu modellerin elde edilme süreçleri ve kullanıldığı yerler ile ilgili günümüze kadar birçok araştırma yapılmıştır ve halen yapılmaktadır. 0-2 yaş sağlıklı çocukların baş çevresine ilişkin gelişimin izlenmesinde, doğrusal olmayan Gompertz, Lojistik ve Monomoleküler modelleri kullanılmıştır [3]. Esmer ve Siyah Alaca dişi sığırlarda ağırlık-yaş değiş̧imini açılamak amacıyla iki doğrusal (kuadratik ve kübik modeller) ve beş doğrusal olmayan model (Brody, Bertalanffy, Lojistik, Gompertz ve Richards modelleri) kullanılmıștır [4]. Bir diğer çalışmada Von V. Bertalanffy büyüme modeli kullanılarak Tarsus-Karabucak-Okaliptüs ağaçlandırma sahalarından elde edile verilerle Eucalyptusgrandis W. Hillex Maiden ağacı için ortalama bir boylanma denklemi elde edilmiş ve çalışma alanı için boylanmanın alt ve üst sınırları saptanmıştır [5]. Karacabey Merinosu x Kıvırcık melezi kuzuların doğum - 101 günlük yaşlar arası dönemde göstermiş oldukları canlı ağırlıklar kullanılarak büyümenin zamana göre değişimini ifade eden çeşitli büyüme eğrilerine ilişkin parametrelerin tahmini ile büyüme eğrilerinin performansları karşılaştırılmıştır. $\mathrm{Bu}$ amaçla Gompertz, Lojistik ve doğrusal model kullanılmıștır [6]. Simental x Güney 
Anadolu Kırmızısı G1 ve F1xG1 genotiplerine ilişkin beden ölçüleri için doğrusal ve doğrusal olmayan lojistik büyüme modelleri oluşturulmuştur. Doğrusal ve lojistik büyüme modellerine ait artıklarda ortaya çıabilecek otokorelasyon sorunu incelenmiştir [7].

Biz de bu çalışmada hiperlipidemi hastalarının Toplam Kolesterol, LDL, Trigliserit ve HDL seviyelerinin farklı regresyon modelleriyle tahminini ve yaşa göre değişiminin belirlenmesini amaçladık.

\section{YÖNTEMLER}

Araştırmamız, İnönü Üniversitesi Turgut Özal Tıp Merkezi Kardiyoloji bölümüne müracaat eden 1278 hiperlipidemi hasta üzerinde gerçekleştirilmiştir. Veriler, Kardiyoloji polikliniğinde tedavi gören hastaların 01.09.2010 - 31.07.2011 tarihleri arasındaki kayitlarından retrospektif olarak elde edilmiştir. Araştırmada veri toplama aracı olarak hasta dosyaları ve vaka kayıtları kullanılmıştır. $\mathrm{Bu}$ süreçte, hastanenin genel bilgi merkezinden yetkililerin gözetiminde hasta hakları ve gizlilik durumları ihlal edilmeden verilerin excel dosyası formatındaki hali edinilmiştir. Veri setinde hiperlipidemi hastalarını belirlemek için kardiyoloji biriminden yardım alınmıștır. Eksik ve hatalı veriler ile aşırı değişkenlik sorunlarının önlenebilmesine yönelik denetimler ve gerekli ise işlemler yapılmıştır. Veri setindeki aşırı (aykırı) değer içeren gözlemler çalışmadan çıkarılmış olup, ham verilerin işlenmesiyle büyüme modelleri elde edilmiştir. Her bir hiperlipidemik değer için yaşa göre ayrı ayrı modelleme yapılmıştır. Araştırmada elde edilen verilerin çözümlenmesi için SPSS 21 (Statistical Package for the Social Sciences) ve NCSS 2004 (Number Cruncher Statistical System) paket programları kullanılmıştır. Çalışmamızda üzerinde çalışılan modeller;
Doğrusal model $Y=\alpha+\beta X+\varepsilon$

Kuadratik model $Y=\beta_{0}+\beta_{1} x+\beta_{2} x^{2}+\varepsilon$

Lojistik model $Y=\frac{\alpha}{1+\beta e^{-\kappa x}}$

Gompertz model $Y=\alpha e\left\{-\beta e^{-\kappa x}\right\}$

Üstel model $Y=\beta_{0} e^{-\beta_{1} x}+\varepsilon$

Regresyon modellerinde; Y: $\mathrm{x}$ zamanındaki gözlenen özelliği, $\alpha$ : asimptotik büyüklüğü, $\beta$ : büyüme eğrisini tanımlayan bir sabiti, $\kappa$ : büyüme hızını ve e: tabii logaritmayı, $\varepsilon ; \mathrm{E}(\varepsilon)=0$

ve $\operatorname{var}(\varepsilon)=\sigma^{2}$ olacak şekilde korelasyonlu olmayan bir hata terimini ifade etmektedir [3].

Regresyon modelinin doğrusal olup olmamasına göre çeşitli teknikler aracılığı ile parametre tahmini değerlendirmeleri yapılabilmektedir (En Küçük Kareler Yöntemi, Maksimum Olabilirlik Yöntemi vs) [8]. En küçük kareler (EKK) yönteminde amaç bağımlı ve bağımsız değişkenler için regresyon doğrusunun grafiğinde yer alan noktalara en yakın geçen doğrusal denklemi tahmin etmektir. Yani noktaları en iyi açıklayan doğrunun denklemini tahmin etmektir [9].

EKK yöntemi $\beta_{0}$ ve $\beta_{1}$ parametrelerinin kestirimleri olan $\hat{\beta}_{0}$ ve $\hat{\beta}_{1}$ 'nın farkını en küçük yapacak biçimde aşağıdaki gibi belirler. $\mathcal{E}$ hata terimi olmak üzere;

en $k \ddot{u} c ̧ \ddot{u} k \sum_{i=1}^{n} \hat{\varepsilon}_{i}^{2}=$ en küçük $\sum_{i=1}^{n}\left(Y_{i}-\hat{Y}_{i}\right)^{2}$

Ancak EKK yöntemi bir takım varsayımlara sahip olduğundan ve doğrusallık gerektirdiğinden doğrusal olmayan regresyonda bu yöntem yerine doğrusal olmayan en küçük kareler veya en çok olabilirlik (EÇO) yöntemleri ile parametre tahmini yapılmaktadır. 
EÇO yönteminin ardında yatan temel düşünce; örneklem verisinin olabilirlik olasılığını maksimize eden parametreleri belirlemektir [10] Yani;

$\ln \ell\left(\beta, \sigma^{2}\right)=-\frac{n}{2} \ln \left(2 \pi \sigma^{2}\right)-\frac{1}{2 \sigma^{2}} \sum_{i=1}^{n}\left[y_{i}-f\left(x_{i}, \beta\right)\right]^{2}$

eşitliğini maksimize etmek demektir. $\left(\ell\left(\beta, \sigma^{2}\right)\right.$ : Olabilirlik fonksiyonu ve $\sigma^{2}=\varepsilon$ varyansı)

Bahsi geçen modellemelerden hangisinin en iyi uyumu gösterdiğini belirlemek için kadın ve erkek hastalar için uyum iyiliği ölçütleri olan HKO' nun küçüklüğü, $\mathrm{R}^{2}$ değerlerinin büyüklüğü ve AIC-SIC (Akaike information criterion- Schwarz information criterion) bilgi kriterlerinin küçüklüğü bakımından en iyi sonuçları veren model incelendi.

$$
A I C=n \log \left(\frac{R S S}{n}\right)+2 k
$$

ve

$$
S I C=n^{k / n} R S S / n
$$

Yukarıdaki eşitlikte; RSS artık kareler toplamını, k bilinmeyen parametreli olabilirlik fonksiyonu ifade etmektedir.

\section{BULGULAR}

Araştırma 607 (\%47,6) kadın ve $671(\% 52,4)$ erkek, toplam 1278 hiperlipidemi hasta üzerinde yapılmıştır. Kadın ve erkek hastaların yaş ortalaması (yıl) sırasıyla 57,64 $\pm 12,53$ ve $57,28 \pm 12,92$ 'dir (Tablo 1). Büyüme eğrilerinin uyumunun incelenmesinde açıklayıcılık katsayısı $\mathrm{R}^{2}$, HKO, AIC ve SIC bilgi kriterleri değerleri dikkate alındığında, Doğrusal, Üstel, Kuadratik, Lojistik ve Gompertz modelleri, hastaların Kolesterol, Trigliserit, HDL ve LDL değerlerinin bulunmasında başarılı sonuçlar vermiştir.

Tablo1: Yaș değerleri için Cinsiyete göre tanımlayıcı istatistikler

\begin{tabular}{cccccc} 
& Sayı & $\%$ & $X_{ \pm \text {SD }}$ & Minimum & Maximum \\
\hline Kadın & 607 & 47,60 & $57,64 \pm 12,53$ & 21,00 & 87,00 \\
Erkek & 671 & 52,40 & $57,28 \pm 12,92$ & 18,00 & 89,00 \\
\hline
\end{tabular}

Söz konusu modeller kullanılarak kadın hastalar için incelenen modellere ait açıklayıcılık katsayısı, HKO ve bilgi kriteri değerleri Tablo 2 ve Tablo 3 de verilmiştir. Hemen her yaş grubu için tablo değerleri incelendiğinde, kadın ve erkek hastalar için uyum iyiliği ölçütleri olan HKO' nun küçüklüğü, $\mathrm{R}^{2}$ değerlerinin büyüklüğü ve bilgi kriterlerinin küçüklüğü bakımından değerlendirildiğinde, kadın hastalarda; Kolesterol değerleri için uyum iyiliği ölçütleri en iyi büyüme modeli Kuadratik model, LDL değerleri için uyum iyiliği ölçütleri en iyi büyüme modeli Gompertz büyüme modeli, Trigliserit değerleri için uyum iyiliği ölçütleri en iyi büyüme modeli Lojistik büyüme modeli, HDL değerleri için uyum iyiliği ölçütleri en iyi büyüme modeli Üstel modeldir.

Erkek hastalarda ise; Kolesterol değerleri için uyum iyiliği ölçütleri en iyi büyüme modeli Gompertz büyüme modeli, LDL değerleri için uyum iyiliği ölçütleri en iyi büyüme modeli Doğrusal model, Trigliserit değerleri için uyum iyiliği ölçütleri en iyi büyüme modeli Üstel model, HDL değerleri için uyum iyiliği ölçütleri en iyi büyüme modeli Doğrusal modeldir. 
Tablo 2: Kadın Hastalar için uyum iyiliği değerleri

\begin{tabular}{|c|c|c|c|c|c|}
\hline & & R2 & нко & AIC & SIC \\
\hline \multirow{5}{*}{ Kolesterol } & Doğrusal & 0,39 & 106,38 & 110,53 & 118,91 \\
\hline & Kuadratik & 0,54 & 81,21 & 105,87 & 95,92 \\
\hline & Üstel & 0,38 & 107,73 & 110,83 & 120,42 \\
\hline & Gompertz & 0,52 & 84,43 & 106,76 & 99,72 \\
\hline & Lojistik & 0,52 & 84,13 & 106,68 & 99,37 \\
\hline \multirow{5}{*}{ LDL } & Doğrusal & 0,50 & 32,41 & 7,56 & 3,65 \\
\hline & Kuadratik & 0,53 & 30,88 & 7,61 & 3,68 \\
\hline & Üstel & 0,50 & 32,71 & 7,58 & 3,68 \\
\hline & Gompertz & 0,56 & 29,29 & 7,5 & 3,49 \\
\hline & Lojistik & 0,56 & 29,35 & 7,51 & 3,5 \\
\hline \multirow{5}{*}{ Trigliserit } & Doğrusal & 0,51 & 521,90 & 147,14 & 583,38 \\
\hline & Kuadratik & 0.60 & 428.80 & 144.16 & 506.47 \\
\hline & Üstel & 0,47 & 557,63 & 148,67 & 623,32 \\
\hline & Gompertz & 0,60 & 432,23 & 144,35 & 510,52 \\
\hline & Lojistik & 0,60 & 428,22 & 144,13 & 505,78 \\
\hline \multirow{5}{*}{ HDL } & Doğrusal & 0,45 & 13,67 & 50,82 & 15.56 \\
\hline & Kuadratik & 0,45 & 13,94 & 52,71 & 17,01 \\
\hline & Üstel & 0,45 & 13,63 & 50,75 & 15.50 \\
\hline & Gompertz & 0,45 & 13,98 & 52,76 & 16.96 \\
\hline & Lojistik & 0,45 & 13,98 & 52,75 & 16.95 \\
\hline
\end{tabular}

Tablo 3: Erkek Hastalar için uyum iyiliği değerleri

\begin{tabular}{|c|c|c|c|c|c|}
\hline & & R2 & НКо & AIC & SIC \\
\hline \multirow{5}{*}{ Kolesterol } & Doğrusal & 0,44 & 98,27 & 74,83 & 113,25 \\
\hline & Kuadratik & ,46 & 96,76 & 76,12 & 119,57 \\
\hline & Üstel & 0,43 & 98,97 & 74,12 & 108,24 \\
\hline & Gompertz & 0,48 & 94,05 & 76,12 & 119,57 \\
\hline & Lojistik & 0,48 & 94,16 & 76,12 & 119,57 \\
\hline \multirow{5}{*}{ LDL } & Doğrusal & 0,73 & 19,87 & 47,25 & 23,02 \\
\hline & Kuadratik & 0,73 & 20,51 & 49,24 & 25,53 \\
\hline & Üstel & 0,73 & 19,89 & 47,25 & 23,03 \\
\hline & Gompertz & 0,73 & 20,51 & 49,24 & 25,53 \\
\hline & Lojistik & 0,73 & 20,52 & 49,25 & 25,53 \\
\hline \multirow{5}{*}{ Trigliserit } & Doğrusal & 0,47 & 839,74 & 114,22 & 995,28 \\
\hline & Kuadratik & 0,47 & 863,55 & 76,12 & 1096,35 \\
\hline & Üstel & 0,47 & 839,02 & 114,21 & 962,58 \\
\hline & Gompertz & 0,47 & 863,82 & 116,22 & 1060,06 \\
\hline & Lojistik & 0,47 & 863 & 116,21 & 1059,28 \\
\hline \multirow{5}{*}{ HDL } & Doğrusal & 0,48 & 9,97 & 37,06 & 11,55 \\
\hline & Kuadratik & 0,48 & 10,29 & 39,06 & 12,81 \\
\hline & Üstel & 0,48 & 9,97 & 37,07 & 11,55 \\
\hline & Gompertz & 0,48 & 10,29 & 39,07 & 12,81 \\
\hline & Lojistik & 0,48 & 10,3 & 39,07 & 12,81 \\
\hline
\end{tabular}

Bu sonuçlardan kadın hastalarda, Kolesterol değerleri için Kuadratik model, LDL değerleri için Gompertz büyüme modeli, Trigliserit değerleri için Lojistik büyüme modeli, HDL değerleri için üstel model; erkek hastalarda Kolesterol değerleri için Gompertz büyüme modeli, LDL değerleri için Doğrusal model, Trigliserit değerleri için Üstel model, HDL değerleri için Doğrusal model yaşa göre hiperlidemik değerleri tanımlamada diğer modellere göre daha başarılıdırlar.

Kadın hastalar için Grafik 1 de Kolesterol değerleri için en başarılı sonuç Kuadratik modelden ve Grafik 2 de LDL değerleri için en iyi uyum değerleri Gompertz modelden elde edilmiştir. Kadın hastalar için Grafik 3 te HDL değerleri için en başarılı sonuç Üstel modelden ve Grafik 4 te Trigliserit değerleri için en iyi uyum değerleri Lojistik modelden elde edilmiştir.

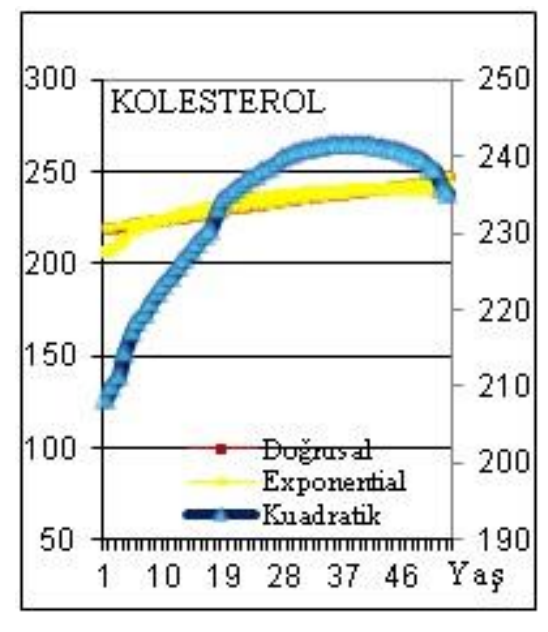

Grafik 1: En iyi uyum Kuadratik model

Erkek hastalar için Grafik 5 te Kolesterol değerleri için en başarılı sonuç Gompertz modelden ve Grafik 6 da LDL değerleri için en iyi uyum değerleri Doğrusal modelden elde edilmiştir. Erkek hastalar için Grafik 7 de Trigliserit değerleri için en başarılı sonuç Üstel modelden ve Grafik 8 de HDL değerleri için en iyi uyum değerleri Doğrusal modelden elde edilmiştir. 


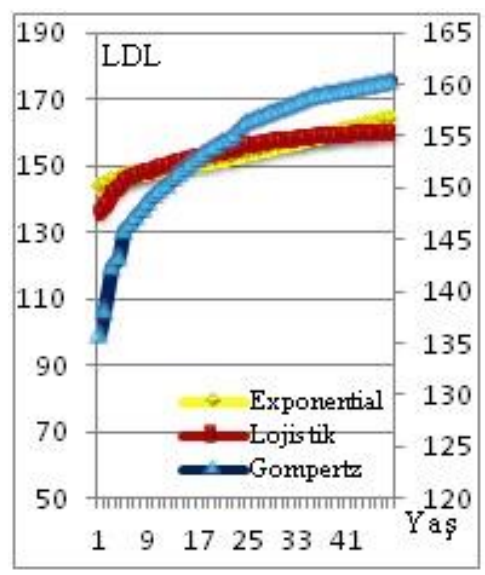

Grafik 2: En iyi uyum Gompertz model

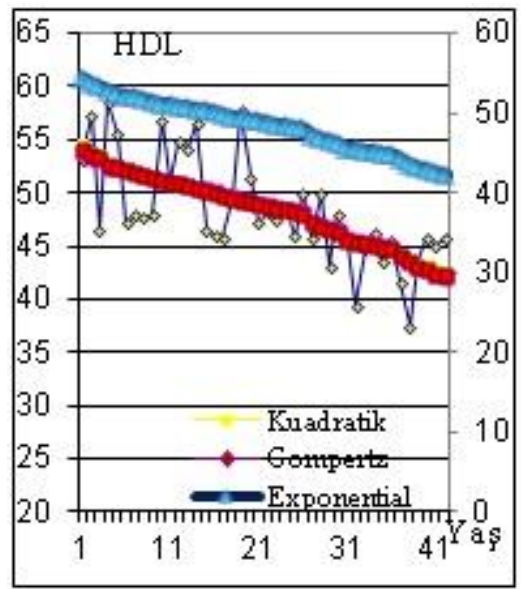

Grafik 3: En iyi uyum Üstel model

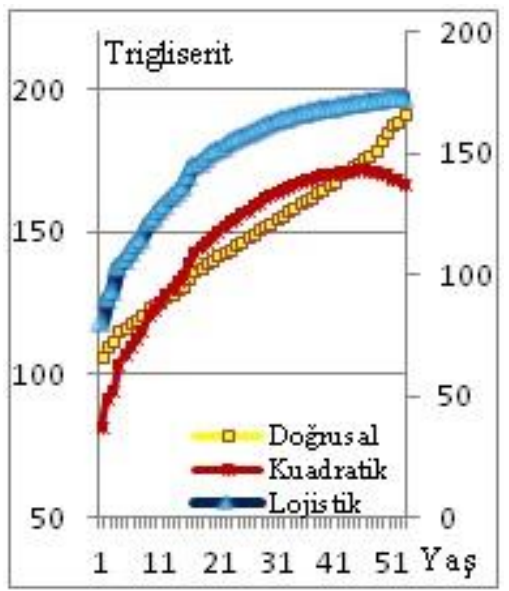

Grafik 4: En iyi uyum Lojistik model

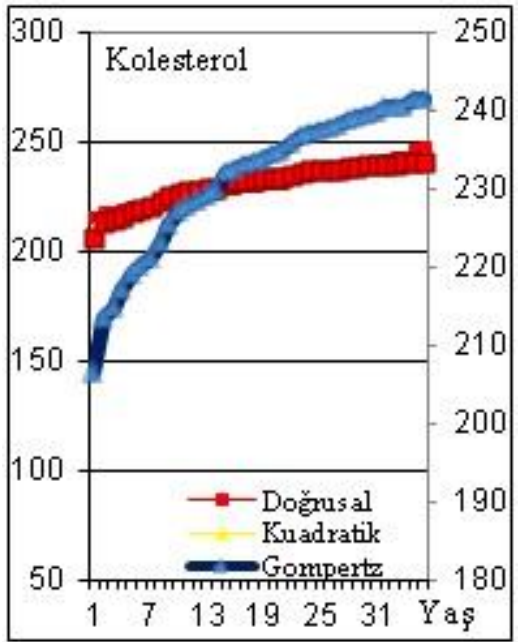

Grafik 5: En iyi uyum Gompertz model

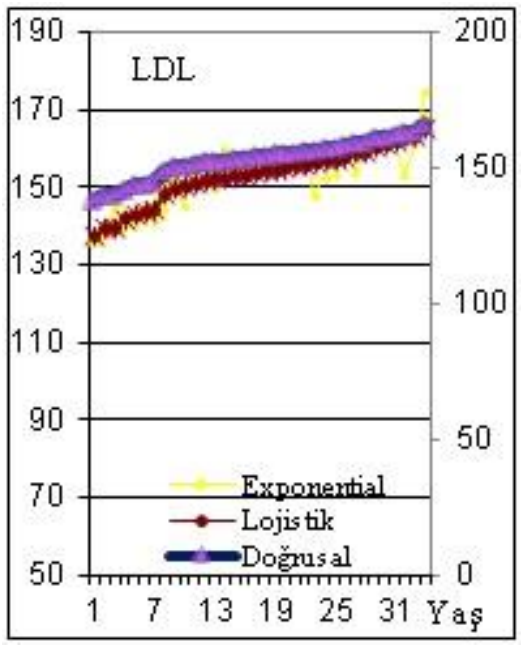

Grafik 6: En iyi uyum Doğrusal model

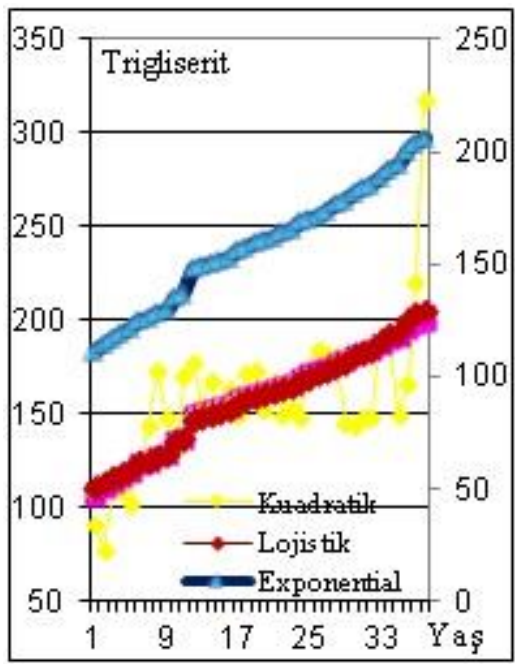

Grafik 7: En iyi uyum Üstel model 


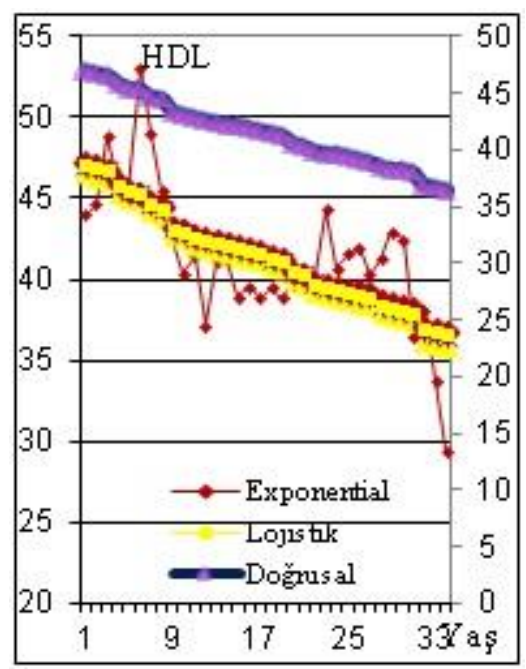

Grafik 8: En iyi uyum Doğrusal model

\section{TARTIŞMA}

Kolesterol yaşam için gerekli olan mum kıvamında yağımsı bir maddedir. Beyin, sinirler, kalp, bağırsaklar, kaslar ve karaciğer başta olmak üzere tüm vücutta yaygın olarak bulunur. Kanda çok az miktarda kolesterol bulunması yeterliyken, her zaman istenilen değerde olmayıp, yüksek değerde seyredebilir. Kanda kolesterol düzeyinin yüksek olması da, kalp ve beden sağlığı için çok önemli bir risk faktörünü oluşturur. Kanda kolesterol yüksek bulununca, bu yağ kıvamındaki madde yıllar içinde yavaş yavaş damar duvarında birikir. Bunun sonucunda kan damarları sertleşir, daralır, hatta tıkanır. Kolesterolün yüksek olması sadece kalp sağlığını etkilemez. Yüksek kolesterol aynı zamanda beyni besleyen damarlarda tıkanma veya daralma, felç, konuşma bozukluğu, dengesiz yürüme ve bilinç kaybına da yol açar. Bununla birlikte, sanılanın aksine kolesterol ile yüksek tansiyon arasında doğrudan bir ilişki yoktur. Ama her ikisi de birbirlerinin kan damarlarına verdiği zararı artırır, ortaya çıkmasını kolaylaştırır. Kolesterolün beden sağlığı üzerindeki etkileri oldukça fazladır ve yüksek tansiyon gibi genellikle belirti vermeden sinsi bir şekilde ilerler. Bazı kişilerin ise ciltlerinde ve göz bebeklerinde hafif sarı bir renk değişimi görülür. Kolesterol testi ana damarların sağlığı hakkında bilgi edinilmesini ve dünyadaki ölüm nedenleri arasında birinci sırada yer alan kalp krizinin ilk sinyallerinin alınmasını sağlar [11].

$\mathrm{Bu}$ çalışmada yaşa göre kolesterol ölçümlerinin tahmininde farklı modeller kullanılarak büyüme eğrileri çizilmiştir. Tahmin edilen bu modeller kullanılarak kolesterol değerleri tahmin edilebilir. Böylece normalden sapmaların değerlendirilmesinde bu modellerden yararlanılabilir. Tahmin modellerinin veri yapisina uyumunun bir göstergesi açılklayıcılık katsayısı $\left(\mathrm{R}^{2}\right)$ değeridir. Açıklayıcılık katsayısının büyüklügü modelde kullanılan bağımsız değişkenin ve modelin bağımlı değiş̧keni açıklama düzeyini gösteren bir ölçüttür.

Kadın ve erkek hastalar için olușturulan Doğrusal, Kuadratik, Üstel, Gompertz ve Lojistik tahmin modellerine ait açıklayıcılık katsayısı değerleri, kadın hastalarda \%45 ile \%60 arasında gerçekleşmiştir. Tahmin modelleri arasında uyumun bir göstergesi olan $\mathrm{R}^{2}$ açısından kadın hastalarda; Kolesterol değerleri için uyum iyiliği ölçütleri en iyi büyüme modeli Kuadratik model ve $\mathrm{R}^{2}$ değeri \%54, LDL değerleri için uyum iyiliği ölçütleri en iyi büyüme modeli Gompertz büyüme modeli ve $\mathrm{R}^{2}$ değeri $\% 56$, Trigliserit değerleri için uyum iyiliği ölçütleri en iyi büyüme modeli Lojistik büyüme modeli ve $\mathrm{R}^{2}$ değeri $\% 60$, HDL değerleri için uyum iyiliği ölçütleri en iyi büyüme modeli Üstel model ve $\mathrm{R}^{2}$ değeri $\% 45^{\prime}$ dir.

Erkek hastalar için oluşturulan Doğrusal, Kuadratik, Üstel, Gompertz, Lojistik tahmin modellerine ait açıklayıcılık katsayısı değerleri ise \%45 ile \%73 arasında gerçekleşmiştir. Tahmin modelleri arasinda uyumun bir göstergesi olan $\mathrm{R}^{2}$ açısından erkek hastalarda; Kolesterol değerleri için uyum iyiliği ölçütleri en iyi büyüme modeli Gompertz büyüme modeli ve $\mathrm{R}^{2}$ değeri \%48, LDL değerleri için uyum iyiliği ölçütleri en iyi büyüme modeli Doğrusal model ve $\mathrm{R}^{2}$ değeri \%73, Trigliserit değerleri için uyum iyiliği ölçütleri en iyi 
büyüme modeli Üstel model ve $\mathrm{R}^{2}$ değeri $\% 47$, HDL değerleri için uyum iyiliği ölçütleri en iyi büyüme modeli Doğrusal model ve $\mathrm{R}^{2}$ değeri $\% 48$ ' dir.

$\mathrm{R}^{2}$ değerlerinin yüksek olması modelin açıklayıcılık oranının yüksek olduğu anlamına gelmektedir. Çalışmada açıklayıcılık katsayısı; hastaların yaşına göre incelenen değişkenlerin değerlerini tahmin etme düzeyini ifade etmektedir. Kalan kısmı açıklamada ise başka etmenlerin olabileceği düşünülebilir. Yapılan regresyon çalışmalarında kullanılan veriler ile oluşturulan modeller arasında fark çıkması beklenebilir. $\mathrm{Bu}$ farkın mümkün olduğunca küçük olması, model tahminlerinde arzu edilen bir durumdur. Bu amaçla hesaplanan HKO ve bilgi kriteri değerleri bu kapsamda modelin uyumu açısından dikkate alınmıştır. "0-2 Yaş sağlıklı çocukların baş çevresine ilişkin gelişimin izlenmesi için büyüme eğrileri" [3] isimli çalışmada büyüme eğrilerinin performasları belirlenirken, açıklayıcılık katsayısı $\left(\mathrm{R}^{2}\right)$ ve hata kareler ortalaması (HKO) dikkate alınarak uyum performasları değerlendirilmiştir. "Determination of Growth Curves in Young Angora Goats" konulu çalışmada uyum iyiliği için sadece açıklayıcılık katsayısı ( $\left.\mathrm{R}^{2}\right)$ kullanılmıştır [12]. "Anadolu Mandası Malaklarında Büyüme Eğrisinin Çeşitli Doğrusal Olmayan Modeller Kullanılarak Karşılaştırılması" bu çalışmada da modeller karşılaştırılırken açıklayıcılık katsayısı $\left(\mathrm{R}^{2}\right)$ ve hata kareler ortalaması (HKO) dikkate alınarak uyum performasları değerlendirilmiştir [13]. Çalışmamızda bu ölçütlere ek olarak bilgi kriterlerini de ekleyerek daha başarılı sonuçlar elde edilmiştir.

Doğrusal, Kuadratik, Üstel, Gompertz ve Lojistik büyüme modellerine ilişkin, belirli aralıktaki yaş grupları için oluşturulan Kolesterol, LDL, Trigliserit ve HDL değerleri için çizilen grafiklerde, eğrilerin benzer oldukları görülmektedir.

Sonuç olarak, doğrusal olmayan hiperlipidemik değerlerin tahmininde farklı modellerin farklı performans gösterdiği belirlenmiștir. Hiperlipidemi değerleri izleminde, bu modellerden elde edilen büyüme eğrilerinin kullanılmasının yararlı olacağı düşünülmektedir.

Çalışmamız 20-23 Ağustos 2013 tarihinde, Didim/Aydın'da Uluslararası Katılımlı 15. Ulusal Biyoistatistik Kongresinde, P11 numara ile poster bildiri olarak sunulmuştur.

Çıkar Çatışması Beyanı: Yazarlar çıkar çatışması olmadığını bildirmişlerdir.

Finansal Destek: Bu çalışma her hangi bir fon tarafından desteklenmemiştir.

Declaration of Conflicting Interests: The authors declare that they have no conflict of interest.

Financial Disclosure: No financial support was received.

\section{KAYNAKLAR}

1. Şahinbaşoğlu ZZ. Doğrusal olmayan regresyonda bazı eğrisellik ölçüleri. Yıldız Teknik Üniversitesi Fen Bilimleri Enstitüsü İstatistik Anabilim Dalı Yüksek Lisans Tezi, İstanbul, 2005.

2. Çevik M. Doğrusal olmayan bayesçi regresyon ve yüksek frekanslı ses sistemlerinde bir uygulama. Yıldız Teknik Üniversitesi Fen Bilimleri Enstitüsü İstatistik Anabilim Dalı, Yüksek Lisans Tezi, İstanbul, 2009.

3. Alasulu N, Çolak C, Orman MN, ve ark. 0-2 Yaş sağlıklı çocukların baş çevresine ilişkin gelişimin izlenmesi için büyüme eğrileri. Ankara Üniversitesi Tıp Fakültesi Mecmuası. 2006; 59:89-92.

4. Bayram B, Akbulut Ö. Esmer ve siyah alaca sığırlarda büyüme eğrilerinin doğrusal ve doğrusal olmayan modellerle analizi. Hayvansal Üretim. 2009; 50:33-40.

5. Yıldızbakan A, Yılmaz E, Akgün C. Von bertalanffy boyca büyüme modelinin okaliptüste (eucalyptus grandis w. hill ex maiden) uygulanması. Doğu Akdeniz Ormancılık Araștırma Müdürlüğü Doa Dergisi. 2005; 11:35-52.

6. Yıldız G, Soysal Mİ, Gürcan EK. Tekirdağ ilinde yetiştirilen karacabey merinosu $\mathrm{x}$ kıvırcık melezi kuzularda büyüme eğrisinin farklı modellerle belirlenmesi. Tekirdağ Ziraat Fakültesi Dergisi. 2009; 6:11-9. 
7. Çolak C, Orman MN, Ertuğrul O. Simental x güney anadolu kırmızısı sığırlarına ait beden ölçüleri için basit doğrusal ve lojistik büyüme modeli. Ankara Üniv Veterinerlik Fakültesi Dergisi. 2006; 53:195-9.

8. Ünlü AR. Doğrusal olmayan regresyon modelleri ve bilgisayarlı çözümleme. Marmara Üniversitesi Fen Bilimleri Enstitüsü Matematik Anabilim Dalı, Yüksek Lisans Tezi, İstanbul, 2006.

9. Gök IYY. Vadeli piyasalarda samuelson hipotezinin geçerliliğinin garch ve lineer regresyon modelleriyle test edilmesi: Vadeli işlem ve opsiyon borsasında bir uygulama. Süleyman Demirel Üniversitesi Sosyal Bilimler Enstitüsü İşletme Anabilim Dalı, Yüksek Lisans Tezi, Isparta, 2009.

10. Börüban C. Firmaların mali başarısızlıklarının ön görülmesinde diskirminant analizi ve lojistik regresyon analizi yöntemlerinin karşılaştırılması. Marmara Üniversitesi Sosyal Bilimler Enstitüsü Ekonometri Anabilim Dalı, Yüksek Lisans Tezi, İstanbul, 2009.
11. Saran N. Yulaf beta-glukanının hafif hiperkolesterolemik bireylerin serum total kolesterol ve ldl kolesterol düzeylerine etkisi. Beslenme ve Diyetetik Anabilim Dalı, Yüksek Lisans Tezi, İstanbul, 2014.

12. Özdemir H, Dellal G. Determination of growth curves in young angora goats. Ankara Üniversitesi Ziraat Fakültesi Tarım Bilimleri Dergisi. 2009; 15:358-362

13. Şahin A, Ulutaş Z, Karadavut U, ve ark. Anadolu mandası malaklarında büyüme eğrisinin çeşitli doğrusal olmayan modeller kullanilarak karşılaştırılması. Kafkas Üniversitesi Veterinerlik Fakültesi Dergisi. 2014; 20:357-362 
Dicle Tıp Dergisi / Dicle Medical Journal

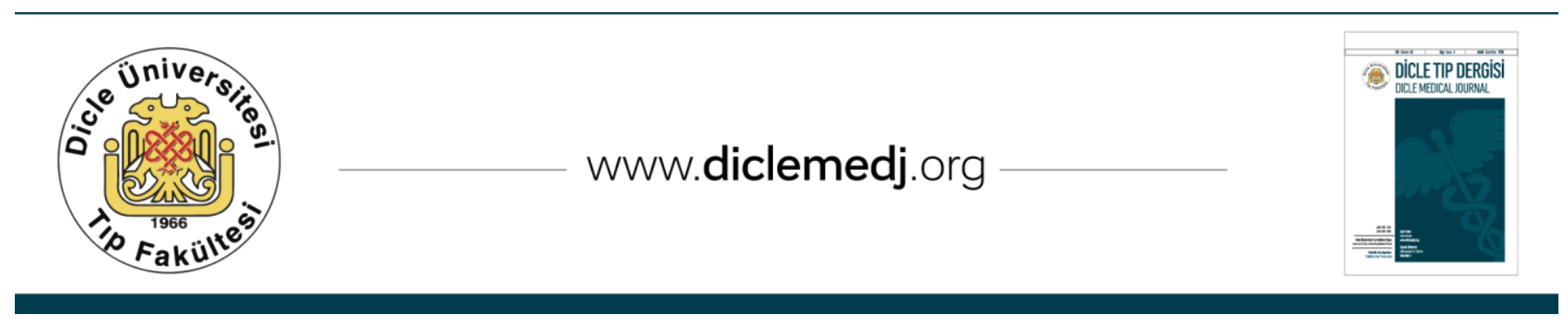

